\title{
'As Human Beings and As Workers': Sex Worker Unionization in Karnataka, India
}

\author{
Gowri Vijayakumar, University of California-Berkeley, USA \\ Shubha Chacko, Aneka, India \\ Subadra Panchanadeswaran, Adelphi University School of Social Work, USA
}

\begin{abstract}
'Sex work is work' has been a central claim in sex workers' activism since at least the 1970s. But what are the implications for such a claim in the context of labor organizing? What promise does the labor movement hold for sex workers facing state violence; oppression on the basis of class, gender, sexuality, and caste; and criminalization? How can sex workers' assertions of 'worker' identity invigorate the labor movement? As a key site of sex worker activism in the Global South, India offers a unique opportunity for an examination of sex workers' collective struggles. This article uses the experience of the Karnataka Sex Workers Union (KSWU) to reflect on the promise and limits of labor perspectives for sex workers.
\end{abstract}

\section{KEYWORDS}

Gender; India; informal labor; sexuality; sex work.

\section{Introduction}

Sex workers are most often perceived by the state as victims to be assisted, criminals to be arrested, or targets for HIV-related public health interventions. However, sex worker activists have worked to position sex work as a form of reproductive labor (Chapkis, 1997; Delacoste and Alexander, 1998; Fortunati, 1995; Kempadoo and Doezema, 1998; Leigh, 1997; McClintock, 1993; Pheterson, 1993), especially in response to regulatory regimes that criminalize sex work, and feminist 'abolitionists' who see sex work as intrinsically immoral and a form of gender-based violence (Barry, 1984; Barry, 1996; Dworkin, 1993; Farley, 2003; MacKinnon, 1993; MacKinnon, 2011). 'Sex work is work' is thus a central claim in sex workers' activism (Chateauvert, 2014; Grant, 2014; Gall, 2007; Gall, 2012). This paper considers how this labor framework has been put into practice in sex workers' organizing. What are the prospects for sex worker collective action in trade-unioninspired structures that seek to organize within the labor movement, especially in the Global South (Sukthankar, 2012)? How might sex worker unions offer lessons for the redefinition of work within labor organizing (Shah, 2003)? What practical challenges emerge as sex workers attempt to unionize? We examine the synergies and tensions involved in sex workers' labor organizing through critical reflection on the Karnataka Sex Workers' Union (KSWU), based in Bangalore, India. ${ }^{1}$

As a key site of large-scale sex worker activism in the Global South, India offers a unique example of sex workers' collective struggles. While estimates of the numbers of sex workers are unstable and politically polarized (Sahni and Shankar, 2013: 12), AIDS surveillance suggests there are at least 868,000 women in sex work in India (NACO, 2012: 8). Sex worker mobilization in 
India has taken shape at the confluence of a long interplay between evolving sex work practices and colonial and postcolonial regulation; large-scale HIV prevention programs run by the state and funded partly by Northern donors; and ongoing dialogues between independent sex worker collectives and feminist, labor, Dalit, and lesbian, gay, bisexual, transgender and intersex (LGBTI) movements. However, the relationship between sex worker movements and labor movements in India has always been fraught (Sukthankar, 2012), with sex workers running up against the moral discomfort of potential movement allies as well as the challenges of the partially criminalized status of sex work.

While its surrounding social taboos suggest that sex work is exceptional, sex workers attempting to organize in trade unions face many of the same challenges other types of informal sector workers face: the stigma of doing 'dirty work' (particularly for waste-pickers or those who work with dead animals or clean toilets); lack of a single target (such as an employer) for organizing; lack of social and legal recognition as workers; and engagement in multiple economic activities and/or employment statuses. Added to these is the dispersed positioning of workers often divided along class, gender, sexuality, or caste lines and operating in secret. Like other forms of informal sector work, sex work is feminized, and workers face exploitation along multiple axes of power. Sex workers also face a uniquely contradictory relationship to the state: they are both partially criminalized and involved in large-scale state-led HIV prevention programs that rely on them to prevent an epidemic in the 'general population.' Organizing strategies for sex workers thus demand a rethinking of the sites and subjects of labor and the possibilities for transformation.

This paper will reflect on sex workers' organizing as an emerging site of informal labor organizing, and its relationship to broader shifts in the nature of 'worker' identity in India. Our discussion draws on a set of eight discussions (see Panchanadeswaran et al. forthcoming for a more detailed discussion) with focus groups of Karnataka Sex Workers' Union (KSWU) leaders, members, and outside allies, but, more centrally, on our own experiences of working with and studying KSWU as researchers and activist supporters. After summarizing the arguments for positioning sex work as labor in the first half of the paper, in the second half we discuss the experiences of the KSWU and its alliance-based, social-movement-inspired approach to unionization. KSWU's approach points to ways in which the category of the 'worker' in India is being redefined to include new relationships between state and workers, and new articulations of gender, sexuality, and class.

\section{Labor Perspectives on Sex Work}

Debates about sex work's status as work have direct implications for the possibilities for sex workers' collective action globally. The rift between an 'oppression' paradigm, which sees sex work as inherently exploitative, and an 'empowerment' paradigm, which sees it as work that can be empowering and even pleasurable (Weitzer, 2009), has long shaped legal battles over the criminalization of sex work. Placing sex work within the labor realm allows sex workers to demand basic labor rights and safe working conditions, as well as linking the concerns of sex workers to broader struggles for class and gender justice (Bindman and Doezema, 1997). Meanwhile, a burgeoning 'rescue industry' (Agustín, 2007) draws ideological support from the arguments of feminist sex work abolitionists, and has sought to rescue and rehabilitate women from prostitution on moral and sometimes religious grounds (Doezema, 2001; Sharma, 2005; Soderlund, 2005; Weitzer, 2007).

In the Global South, anti-sex-work advocacy has often drawn not only on cultural nationalism and moral conservatism, but also on ideological and monetary resources from the North. The image of the victimized Southern prostitute, incapable of choice, has been central to Northern 
'abolitionist' proposals since the nineteenth century (Doezema, 2001), and organizations like the Coalition Against Trafficking in Women (CATW), Christian evangelical groups, and the United States Agency for International Development (USAID) under the Bush administration have all attempted to oppose the growth of sex worker groups promoting a work or labor perspective in India. These abolitionist groups have also promoted legal reforms that further criminalize sex work. In their colonial and postcolonial iterations, such abolitionist organizations have supported law enforcement in conducting irresponsible raid and rescue operations. In the wreckage of the raid, the lives and livelihoods of these ostensibly rescued women become collateral damage, and the selfsatisfied press releases of the rescuers never make mention of their fates. Abolitionist groups have strongly opposed characterizations of sex work as work as 'dangerously misleading', preferring terms such as 'prostitution' and 'sexual exploitation' and arguing that sex work cannot be considered work because it is propelled by 'poverty, violence, and inequality' (Leidholdt, 2000). Of course, poverty, violence and inequality affect many sectors of labor markets: this is not peculiar to sex work alone.

These framings of sex work as work vary: arguments range from positioning sex work as empowering, pleasurable work, aligning sex workers with medical caregivers or therapists, to low-status, informal and sometimes exploitative labor, aligning sex workers with the working class. Meanwhile, sex workers have long organized to assert their position as workers (Chateauvert, 2014; Gall, 2012; Grant, 2014), and scholars have increasingly analyzed sex work as a form of labor (Dewey, 2012). Sex worker activists in Call Off Your Old Tired Ethics (COYOTE), founded in San Francisco in 1972, focused on civil rights and human rights, not always labor rights (Bernstein, 2007; Bernstein, 2010; Jenness, 1990; Jenness, 1993). ${ }^{2}$ Southern sex worker movements have often taken the relationship between sex work and the working class more seriously, seeking to undo the boundary between sex work and other types of low-status informal sector work (Bindman and Doezema, 1997). Compared to 1970s sex worker movements in the United States and Europe, reference to the Global South has added nuance to the concept of sex work as work by situating it in the context of simultaneous choice and exploitation (Boris, Gilmore, and Parreñas, 2010; Davidson, 2002), as a labor process that contains within it both forms of oppression and the basis for collective action and self-determination. Such an approach better represents the ways in which sex workers often describe what they do - as labor comparable to other forms of informal sector labor (Sahni and Shankar, 2013).

Since the 1990s, more and more sex worker organizations globally explicitly saw themselves in line with a trade union model. Organizations of sex workers have lobbied for sex workers' rights in Ecuador, Malaysia, Thailand, South Africa, Uruguay, and India. Several, including the International Union of Sex Workers in the United Kingdom, Red Thread in the Netherlands, and Asociación de Mujeres Meretrices de la Argentina (AMMAR) in Argentina, have formal affiliations with trade union 'umbrella' organizations (Hardy, 2010). Though sex worker organizations vary widely in their concrete relationships to labor movements, organizing formally and informally as unions can play an important symbolic role in affirming sex work's position as labor. Adopting a labor approach allows for an interrogating of the possible injustice of the conditions of work using international instruments, such as the International Labour Organization's (ILO) four pillars of decent work for all, and the International Covenant on Economic Social Cultural Rights, which recognizes the right to work, and places on the State the responsibility to ensure that the work is under 'just and favorable conditions,' with the right to form and join trade unions (Articles 6, 7, and 8).

In India, several groups of sex workers have mobilized around the identity of the 'worker'. Of the many collectives of sex workers around the country, the oldest and most well studied is the Durbar Mahila Samanwaya Committee (DMSC), based in Kolkata (DMSC, 1997; Jana et al., 2004; Ghosh, 2004; Sukthankar, 2012; Restakis, 2013). First formed as an HIV prevention project in 1992, built around the principles of occupational health, DMSC eventually began to position itself 
as a trade union of sex workers. Partly inspired by DMSC and facilitated by national government and international donor funding for HIV prevention programs, sex worker collectives formed throughout India in the 1990s and 2000s, notably Veshya Anyay Mukti Parishad (VAMP) in Sangli in Maharashtra and other collectives in the southern states of Karnataka, Andhra Pradesh, Tamil $\mathrm{Nadu}$, and Kerala. These groups vary widely in structure and ideology, and form two national networks, the National Network of Sex Workers (NNSW) and the All-India Network of Sex Workers (AINSW). Many argue to some extent that sex work is a form of work. Of these groups, the KSWU, discussed in this paper, is the only group we know of to consider itself a trade union alone, without any public health programs.

Studies of sex work in the Global South point to the ways in which the concept of 'work' must be reformulated to accommodate the complex intersections of intimacy and money and the shifting, variable work patterns that characterize sex work. With reference to India, Shah (2003: 75) argues that "the label 'work' may not be adequate to accommodate the social and political complexities of exchanging sex for money," and suggests placing sex work more squarely within the context of poverty, migration, and broader shifts toward informalization in labor regimes globally. Kotiswaran (2011: xiv) suggests that 'It is at the intersections where sex becomes work and work demands sex that sex work needs to be understood, rather than by fetishizing sex as necessarily reciprocal and pleasurable and work as always dignified.' Hernandez-Truyol and Larsen (2005: 406) note that the opposition between a right to work and human rights is a 'false dichotomy': conflating a legitimate critique of the conditions under which prostitution operates with the refusal to recognize prostitution as a form of labor 'means that...complex social [realities] cannot engage the underlying human rights principles invoked, preventing human rights understandings from deepening and expanding.'

Sex work is feminized labor both in its content and embodiment. Sex work offers one of the few opportunities for certain women, men, and transgender women to ensure survival or economic mobility. The low wages that women and sexual minorities are paid, the failure of markets and governments to provide structures that allow them to work, and the manner in which work is organized are all factors that impinge on sex work and those engaging in it (Maher, Pickering, and Gerard, 2012). A labor perspective toward sex work also draws on accounts of gendered labor that include emotional work and therapeutic services (Ehrenreich and Hochschild, 2003; Hochschild, 2003). The sex worker does not sell 'her body'. Rather, the sex worker sells her physical labor by providing sexual services. Sexual labor is affective labor in that it includes emotional, physical, and mental activities and demands abilities to satisfy client's desire to be liked, sexually desired and entertained. Constructing the work that sex workers do as merely being at the receiving end of penetrative sex strips it of its complexity and masks the actual labor and skills involved in sex work (besides a range of other survival strategies that sex workers learn and evolve over time to avoid brushes with the state, goons and vigilante groups). This tendency to devalue and reduce the complexity of the sex workers' working lives is in keeping with the dismissal of the workers in the informal sector as unskilled.

\section{Sex Workers and their Work Conditions in India}

The limited information on sex work in India suggests the fluidity of sex work with other forms of informal, feminized labor. In general, data on scales and patterns of sex work remain scarce. Large-scale data tends to come from state agencies devoted to HIV prevention. Public health studies have used various criteria to distinguish between types of sex workers: practice; mode of operation; mode of organization; nature of the sex work network; place of sex and primary place of solicitation (Buzdugan et al., 2010; Buzdugan, Halli, and Cowan, 2009). However, these 
categorizations often fail to note that typologies of female sex workers are fluid, in response to economic and other environmental pressures.

A recent survey of female, transgender, and male sex workers attempts to correct this pattern. In a report on the female survey respondents, the authors note, 'It is not easy to demarcate women's work into neatly segregated compartments. Sex work and other work come together in ways that challenge the differentiation of sex work as an unusual or isolated activity' (Sahni and Shankar, 2011: 2). A minority of women surveyed had entered sex work directly: most (60\%) had prior or concurrent experience of other labor markets (Sahni and Shankar, 2013: 22). Other occupations combined with sex work included daily wage labor in construction or agriculture, vending, domestic work, sales or tailoring, flower selling, or garment factory work. Women with prior labor market experience came to sex work for economic reasons $(28 \%)$ or because of bad working conditions (7\%), or harassment (8\%), and others because of family (16\%) or migration (2\%) (2013: 35). Sex work also offers flexible timing and quick availability of cash.

Data on Indian sex workers suggests they come from marginalized social backgrounds similar to those of other informal sector workers. Researchers found relatively low levels of schooling among female sex workers, though more than $30 \%$ had completed some secondary schooling (2013: 18). Those who entered directly into sex work had relatively higher levels of schooling (2013: 38). The majority $(60 \%)$ came from rural family backgrounds and $35 \%$ from urban backgrounds. The majority (65\%) also came from poor family backgrounds. About $26 \%$ of female respondents were Dalits, a proportion roughly similar to that of the general population (Census of India 2001). Other studies suggest that among sex workers, there is an overrepresentation of Dalit women. Sex workers in Andhra Pradesh, for example, comprise an overrepresentation of widows and women separated from their partners or husbands, often contending with major financial issues (debt, health issues in the family, lack of any other bread winner) when they enter into sex work (Dandona et al., 2006).

Sex workers work under extremely exploitative and stigmatized conditions, abused by police, goondas (thugs/goons), landlords, neighbors, lodge owners, brothel owners, agents, clients, husbands/partners, government officials and even strangers who see them at work. Within the system sex workers are routinely denied basic entitlements such as ration cards or access to health facilities. Their children also face discrimination in schools, hostels and in society in general. Access to public places - parks, bus stops, places of worship, restaurants etc. - is often unpleasant, difficult or downright traumatic. While many of the challenges Indian sex workers face resemble those facing other poor and marginalized people, these forms of stigma and violence are particularly extreme.

\section{A Contradictory State: Criminalization and HIV Prevention}

A major barrier to sex workers' claim to being workers in India is their legal status. While sex work is not technically illegal in India, existing legislation pertaining to sex workers defines prostitution as sexual exploitation or abuse, not as work, and criminalizes several aspects of sex work. Ambiguities in the law often lead to harassment of sex workers by law enforcement officials.

Indian laws pertaining to sex work have their roots in the colonial period. The Indian Penal Code, introduced in 1860, prohibited prostitution, or the exchange of women for the purposes of prostitution, for those under the age of 18. While the sections of the Indian Penal Code pertaining to sex work remain in force, more recent struggles over sex work and the law trace their roots to the Suppression of Immoral Traffic Acts (SITA) of 1923, originally a series of provincial acts and amended in 1956 after India signed the International Convention for the Suppression of Traffic in Persons and of the Exploitation of the Prostitution of Others in 1950. SITA was amended in 1966 and 1986 and renamed the Immoral Traffic (Prevention) Act (ITPA). The act, after the 1986 amendment, defines prostitution as 'sexual exploitation or abuse of persons for commercial purposes 
or for consideration in money or in any other kind.' While it does not directly penalize prostitution, it penalizes various activities associated with it. The 1986 version of ITPA also criminalizes the soliciting of clients at a distance of 200 meters from a public place. An offender can be held in a corrective institution or rehabilitation home indefinitely.

In May 2006, a controversial amendment to the ITPA was introduced in Parliament, drafted by the Ministry of Women and Child Development (WCD). The bill deleted provisions of the ITPA that penalized soliciting in a public place. Instead, it penalized the clients of sex workers; in reference to the 'Swedish model', all sex workers were considered to be victims of sexual exploitation. The threat of the amendment offered an opportunity for emerging sex worker groups across India to unite around a common cause. After a series of protests, the bill was suspended. In February 2013, the ministry again proposed similar amendments to the ITPA, and yet again faced protest from sex worker groups. More recent legal developments have suggested a shift in approach to sex workers in some branches of government. In February 2011, the Supreme Court, in response to a case regarding the brutal murder of a sex worker in Kolkata, initiated an exercise that included a panel of organizations working with sex workers to examine the concerns of sex workers in India. While the bench did not position sex work as work, it offered a more sincere attempt at 'rehabilitation' than the existing token efforts. The aftermath of the Delhi rape and murder in 2012, and the subsequent protests pushing for legal reforms around sexual violence, resulted in further developments in laws around sex work. The Union Cabinet's rushed ordinance, which toughened laws around sexual violence, included prostitution in the definition of 'exploitation,' thus effectively criminalizing prostitution as a form of trafficking. After another round of protests from the National Network of Sex Workers, the bill passed in March 2013, the Criminal Law (Amendment) Act, omitted the word 'prostitution' from the definition of exploitation.

International legal frameworks vary widely in their approach to sex work. Increasingly, however, UN agencies have moved toward an understanding of sex work as an occupation. The UN Protocol to Prevent, Suppress and Punish Trafficking in Persons, Especially Women and Children, known as the Trafficking in Persons (TIP) Protocol, does not conflate prostitution with trafficking, but does consider trafficking to include 'the exploitation of the prostitution of others,' a slightly ambiguous compromise between sex worker activists and abolitionists (Kotiswaran, 2011). UNAIDS, the United Nations Population Fund (UNFPA) and the World Health Organization (WHO) all recommend the decriminalization of sex work. The ILO, in a 1998 report, called for official recognition of the sex sector, including the right to proper working conditions where sex work is not criminalized (Lim, 1998). Particularly in the context of HIV, the ILO has affirmed its inclusion of sex workers in the category of workers, but has been reluctant to make recommendations to member states.

Particularly in India, there is another dynamic in sex workers' relationship to the state that cannot be ignored: Sexually Transmitted Infections (STI) and HIV prevention programming. Since the nineteenth century, criminal laws restricting sex work have coexisted with state efforts to regulate and extend medical surveillance over sex workers. Early in the HIV/AIDS epidemic, the national response positioned sex workers as key vectors of disease, but also involved them as foot soldiers in disease prevention. Sex worker groups proliferated in part to protect sex workers against the very real threat of disease and in part to protest a state response to the epidemic that reinforced the stigma against them. Some groups, though not all, actively promoted a labor or human rights approach to sex work. Whether or not in an antagonistic way, association with HIV/AIDS prevention offered these groups a platform for visibility and an avenue of support. For example, many HIV/AIDS NGOs and even the National AIDS Control Organization stated opposition to the proposed amendments to the ITPA in 2006. State HIV/AIDS programs have thus simultaneously offered sex workers a claim to citizenship and opened them up to increasing 
surveillance (Ghosh, 2005; Lakkimsetti, 2011). Internationally, the HIV/AIDS epidemic has channeled new resources into sex worker organizing and networking, and many Indian sex worker activists have participated in international movement-building as a result of these resources.

\section{Organizing as Laborers: The Case of the Karnataka Sex Workers' Union}

This is a special day for us as we are observing this May Day for the first time not only as sex workers but also as members of Karnataka Sex Workers Union, the first sex workers union in Karnataka, perhaps in India. We are diverse and work in diverse environments. We are women, men and hijras. We are from cities, towns and villages. We speak Kannada, Tamil, Telugu, and Urdu. We are Hindus, Muslims, and Christians. We are from different castes, cultures, traditions and socio-political backgrounds. We get into sex work for different reasons. But we have all come together as a Workers' Union to fight for our rights, to get our work recognized as legitimate work with the full range of labour rights. (Karnataka Sex Workers Union, 2006)

The Karnataka Sex Workers Union (KSWU) is a trade union of women, men and transgender sex workers, living in the southern state of Karnataka, India. KSWU's approximately 2,500 members pay a joining fee and then a monthly subscription in order to register. The union formed with a rally on May $1^{\text {st }}$, 2006. Subsequently, it was a series of events in June 2007 in Channapatna, Karnataka that forcefully brought home the need for a union for sex workers and galvanized the sex workers. The events commenced with the arrest on June 2, 2007 of four women under the Immoral Traffic (Prevention) Act and the consequent media exposure of the women. A public protest, held to condemn the police complicity in converting a routine process into a sensational trial by media, was disrupted and the protesters were beaten up in the presence of the police by hired goons. In the wake of this attack, KSWU reached out to other supporters and the People's Union for Civil Liberties-Karnataka (PUCL-K) constituted a fact-finding team to enquire into the incidents (PUCL, 2007). This document, which condemned the police, along with other public actions, succeeded in sending a message to the local police that sex workers were able to leverage some support from mainstream organizations. These incidents and their fallout prompted many sex workers to approach KSWU. KSWU distinguished itself from existing HIV prevention NGOs by emphasizing the human rights of sex workers. Geeta, the first General Secretary of KSWU and one of the most outspoken leaders from among the sex workers of Karnataka, said, 'I do not want sympathy. We do not want sympathy. What we want is our rights - as human beings and as workers.' ${ }^{3}$

KSWU emerged as a response to two trends. One was the growing organizing effort of workers in the informal economy, which inspired both sex workers and some of their NGO contacts. This meant that KSWU was positioned not as an organization of professionals who are specialists, but as workers in the unorganized sector. Rather than positing sex workers' rights within the ambit of sexual pleasure or radical sexual choices, this placed them within the labor rights framework - with strong dimensions of gender and class (and to some extent caste). The other was the perceived need to respond to the narrow existing Community Based Organization (CBO) models of HIV prevention intervention. The union emerged as a way to address the issue of sex worker rights, including as workers within state HIV prevention programs. Thus, KSWU conducted a flash protest at the World AIDS Day observation of the Karnataka State AIDS Prevention Society to focus attention on the issues around compromising privacy and confidentiality and forced HIV testing of sex workers and sexual minorities. KSWU was intent on creating a space where sex 
workers could feel a sense of ownership and independence - a space of their own, separate from HIV prevention goals.

KSWU follows a basic democratic structure. Since 2007, KSWU has been holding formal regular elections and through secret ballot has democratically elected the members of its Executive Committee (EC). Major policy decisions are discussed at the Annual General Meeting (AGM), as are broad contours of the plans for the coming year. The EC is (and has always been) composed entirely of sex workers, although the by-laws provide for non-sex-workers to occupy up to two positions. There is a healthy rotation of leadership, with senior leaders often having to make way for emerging ones. To ensure that the EC reflects the diversity of its members there are in-built provisions for representation of male and transgender sex workers (who are much smaller in number) and from the various districts where KSWU is active. A practice of a sex worker who is living with HIV being a member of the EC has also been instituted. The EC meetings are held with some regularity. Discussions of differences and disagreements as well as consensus building, planning, and reflecting on larger strategies take place at these meetings.

The meetings of the Union (member meetings as well as EC meetings) have incorporated elements from Dalit and feminist movements. If a song on the emancipation of Dalits is sung at the beginning of proceedings and the members move on to plan a program for International Women's Day, it is a fairly typical meeting. While seeing itself as an organization that champions the rights of sex workers, KSWU works closely with a range of progressive groups and organizations. KSWU has been affiliated with New Trade Union Initiative (NTUI), a national federation of independent trade unions in India. This affiliation intended to draw from the efforts of other independent unions in terms of organizing strategies as well to benefit from being under a larger umbrella and signal KSWU's solidarity with informal workers.

However, collaborations have not been easy given the 'discomforts around sexuality that characterized the Gandhian, Marxist, or religious philosophies' of some organizations' leadership (Sukthankar, 2012: 257). Some Ambedkarite groups are also uncomfortable with the idea of sex work as it is viewed as a means of subjugation of Dalit women by dominant castes seeking to enforce their social status and economic superiority (Rozario, 2000). Local domestic worker groups, too, have seen KSWU as a challenge to their respectable image. Some feminist critics argue that sex work is an instantiation of patriarchal domination and poverty and must be abolished; on the other hand, they argue that the sex worker makes 'easy money' rather than choosing difficult, low paying and exploitative work in the informal sector.

KSWU has worked steadily to forge these links. Members of KSWU therefore have made a trip to Chhattisgarh to support human rights activist Binayak Sen when he was in jail; have travelled to Kudankulam in Tamil Nadu to express solidarity with those struggling against the nuclear power plant there, and have had animated conversations with the waste-pickers' union in Pune (Aneka et al., 2013). They have lent their energies to a forum called forgenderjustice and have participated in large numbers in a rally pressing for land for Dalits. The issue of pensions for all touched a deep chord in them and they wholeheartedly supported the Pension Parishad, a national campaign for a universal basic pension. KSWU's constant efforts to link with a range of other groups are informed by many different considerations. Without doubt it is a strategy to increase support base and visibility - but the driving impulse is to forge bonds of empathy and solidarity. It stems from an understanding that the process of social transformation requires different marginalized sections of society to come together and work together. KSWU also keeps alive the strong elements of fun and laughter, which most activists abandon somewhere along the way. Besides links to other movements, KSWU is also an active member of the National Network of Sex Workers (NNSW) and currently a less active member of the Asia-Pacific Network of Sex Workers (APNSW). 
An important, and evolving, aspect of KSWU's activism has been its relationship to Non Governmental Organizations (NGO). Given their criminalized status and the unwillingness of many sex workers to come forward and identify as sex workers, as well as the backgrounds of many leaders in the NGO world, KSWU initially looked to NGOs for basic support. NGOs working on sexuality, human rights, and HIV/AIDS played a facilitative role, assisting in mobilization, supporting in the articulation of interests, creating dialogue, and providing space and basic resources. This relationship with the NGOs and supporters has evolved over time, with a gradual shift in power relations. Without doubt the first phase of the relationship was characterized by the supporters and NGOs setting the structure and emphasizing some values and approaches. The sex workers quickly started to assert themselves and partner with the supporters in shaping KSWU. The relationship, however, is not without tensions. KSWU leaders sometimes have felt that the NGO heads have been negligent, indifferent or disrespectful. At other times, NGO supporters have argued that leaders of KSWU were inadequately accountable to their constituencies. These tensions are productive and have strengthened KSWU to assert its identity and gain greater credibility.

Work conditions for sex workers are fundamentally dependent on their relationships with the state and the dynamic intersections of class, caste, and gender inequality that shape their lives. Thus, while rooted in a clear understanding of the importance of coming together and organizing to ensure better quality of work life for ordinary sex workers, KSWU's main activities blur the boundaries between work activities and other aspects of a sex worker's life, going beyond the areas that are traditionally considered the work of a union. As Baldwin (1992: 81) observes, 'a woman's claim on justice ... crucially depends on her success in proving that she is not, and never has been, a prostitute.' KSWU thus often seeks to promote sex workers' full access to civil and human rights of every kind, and legal reform around sex work is one of its major long-term advocacy goals.

More immediately, Union members and leaders support each other in multiple ways, addressing violence, supporting civil rights, and providing emotional support. Leaders and members might visit homes of sex workers or areas where sex workers frequently solicit to gather and disseminate information about KSWU activities. One of the most consistent interventions of KSWU has been responding to calls seeking support through a $24 x 7$ helpline. The sex worker may be harassed or facing violence (or the threat of violence) from the police, goons, at public spaces or at home. Sometimes she is distressed and may be battling with personal issues (including feeling emotionally overwhelmed or even suicidal). The full timers, KSWU members, EC members and/or supporters reach the person as soon as possible. Besides immediate intervention, the issue, if warranted, is followed up for further action - if need be with the help of lawyers, human rights activists, people from the media and/or counselors (depending on the situation). This includes politicizing the issue by sending out petitions, using the media to create greater pressure on the perpetrators, and holding protests and demonstrations. It also involves providing support (material and emotional) to the sex worker/s who require them. For example, in December 2009, KSWU forwarded a formal complaint regarding a woman sex worker who had been sexually harassed by a doctor to several government agencies and human rights organizations; the doctor was suspended and eventually dismissed. KSWU has also intervened to prevent human trafficking. It has responded to violations of confidentiality by the TV media, once pressuring a major television channel to issue an apology for its secretly filmed and sensationalized story about sex workers.

Informal worker movements in India often direct their claims to the state rather than to their employers (Agarwala, 2013). Similarly, KSWU has often worked to expand sex workers' access to social citizenship. For example, many sex workers do not possess ration cards or voters identity cards because of difficulties in providing proof of address or harassment by government agencies. Government health facilities, too, often discriminate against sex workers. KSWU therefore seeks to address some of these immediate concerns of its members, and has provided over 500 sex workers 
with voter identification cards and 100 with ration cards, as well as supported sex workers in settling property and land issues, and helped them access old age and widow pensions. KSWU has also supported the children of sex workers in obtaining admission to schools, buying books, or being placed in hostels. KSWU has also intervened in instances of abuse of sex workers within their families at home, for example, in the case of a sex worker whose family refused to give her a share in the family property and subjected her to tremendous abuse. Eventually, she built her own house just opposite her family house.

KSWU's activities also extend beyond formal mechanisms. Members offer each other emotional and social support, spending time with each other, sharing food and housing with each other, assisting each other with childcare or in accessing health care, or advising each other on clients. This emotional support assumes special significance for sex workers as they often lack other support systems. KSWU serves as a supportive, non-judgmental space, where, as Sheetal, a transgender member, put it, 'we can talk and be ourselves.' These bonds offer members a space to develop new values and experiment and undertake acts of resistance, whether in their everyday lives or in the form of public protest.

The participants in a review of KSWU underlined the gradual development of vigorous modes of open communication and democratic decision-making processes that fostered equality, trust and mutual respect among members (Panchanadeswaran et al., forthcoming). One participant explained,

When it comes to the group, people feel that it is [theirs]....the strength of the organization counts and people know that there is this union... [a] sex workers union with a labor concept and considering me as a labor[er]. The members feel that they have a union, [that] there is space....The space creation is the main thing for me, because that was not there before, and I now have a forum to speak.

Sex workers reiterated their individual journeys toward greater courage to speak out against violations they face on a day-to-day basis through their work with KSWU. Often access to an identity card and formal identification as a worker is cited as a key benefit of KSWU membership, and members often repeat that 'we are not criminals, we are workers and therefore deserve our rights.' Sex workers use their KSWU identity cards to negotiate with police and officials, or even within relationships with partners or clients. Symbolic status as a worker has real effects for sex workers, and, as Agarwala (2013) has found for other informal workers in India, holds deep emotional significance. Though KSWU differs greatly from a traditional trade union, its positioning as a union helps sex workers claim 'worker' identity, while suggesting how the structure of a union might accommodate new forms and strategies.

\section{The Struggle to Articulate 'Worker' Identity}

In contrast to characterizations of sex workers as vectors of HIV or criminals, or victims to be rescued, the category of 'worker' provides an important alternative and resonates with many sex workers' articulations of their lives. However, social stigma, everyday violence on the job, and precarious legal status make sex workers' organizing efforts as 'workers' particularly difficult. At the most basic level, sex workers are not legally recognized as workers, and their organizations are not legally recognized as unions. Collectives in India can be registered under various Acts - as public charitable trusts, as societies, as section 25 companies (non-profit companies), as cooperatives, or as producer companies. However, for formal recognition as a labor organization, the organization has to be registered under the Trade Union Act. ${ }^{4}$ Trade unions traditionally have greater social legitimacy and are able to negotiate a seat at the table in policy-making processes. They also have 
access to additional benefits such as the Employees' State Insurance Act, 1948, or representation in bodies such as the ILO. In 2008, KSWU applied to the Trade Union Registrar (Karnataka) to be registered as a trade union. However the application was rejected on the grounds that sex work is illegal and sex workers have no 'employer'. KSWU is challenging this ruling in the high court. For KSWU, then, the claim that 'sex work is work' has both symbolic and legal implications.

In addition to the legal hurdles of trade union registration, KSWU has faced challenges in maintaining its membership base. For one thing, sex workers are scattered and hidden. Sex workers are diverse along caste, class, and gender lines, and uniting as a single occupational group does not always come naturally. The structure of sex work can also hinder organizing. In Karnataka, as in many parts of South India, sex work is primarily home-based or street-based. Work takes place through one-on-one arrangements with clients picked up on the street, or through networks of phone contacts that do not lend themselves to traditional labor organizing.

When invisibility and ability to 'blend in' is of paramount importance, seeking a 'worker' status may seem counterproductive to potential members. Often, sex workers in Karnataka operate in secret and are uncomfortable talking about sex work in public forums. Loss of anonymity may endanger them, or lead to harassment by authorities and the public, loss of housing, and increased threat of arrest. This has meant sex worker groups often rely on a few particularly vocal leaders responsible for representing a broad-based and diverse constituency. In a context where identifying as a sex worker itself is risky, attracting members to an organization that explicitly states that it is a sex worker organization in its name - unlike other sex worker groups, which often call themselves 'mahila sanghas' or women's groups - is challenging. Further, unlike formal sector unions that might offer tangible and immediate benefits, sex worker unions can provide some benefits, such as identity cards, but their work often hinges on long-term advocacy work to claim labor status without immediate rewards, making it difficult to retain new members.

A dispersed and sometimes transient membership means that KSWU cannot yet operate solely on the basis of membership fees. As a result, the union must draw on external sources of both financial and technical support. While relationships to NGOs mean a source of legitimacy, access to activist networks, and meaningful solidarity, they can also draw ownership away from the rank and file.

An additional threat to KSWU is the fact that the HIV/AIDS epidemic has meant a proliferation of organizations all vying for large numbers of sex worker members and a sizable, but shrinking, pool of public health funding. HIV prevention organizations thus present competition to unions with broader aims but fewer resources: they provide free health services and employ many sex workers as peer educators. KSWU, starkly different in mandate and approach, is often asked to distinguish itself from other sex worker organizations. One response has been to challenge HIV prevention interventions themselves from a labor perspective, for example, demanding full-time pay for peer educators and forcing the closure of NGOs where sex workers were subject to abuse. As a result, some of the NGO/CBO leaders strongly discourage their members from joining the Union.

Sex workers, both criminalized and vital to urban economies, face new challenges as the aesthetics of city redevelopment (Ghertner, 2010; Ellis, 2012) push them further into the margins. The current urban development strategies have aimed to make Bangalore, KSWU's base, a 'world class city' attractive to corporate investors. This has necessarily meant that the city is being imagined as an exclusive one that is increasing hostile to the urban poor as it clears space for 'new affluent citizens and their consumption driven lifestyles' (Birkinshaw and Harris, 2009: 4). In the name of creating 'good investment climate', the focus has been on the infrastructure needs of elite classes (such as flyovers [highway overpasses] and swanky airports) and privatization of public assets, basic services and urban commons. In effect, this has further edged out other citizen concerns. Sex workers are driven out, and sites that supported sex work are increasingly raided. KSWU leaders 
have pointed out that the building of flyovers has meant chopping down of trees, some of which had served as working sites for them. The public parks now have increased security to ensure that people 'behave,' preventing sex workers from 'loitering.' Similarly, increased security has resulted in transgender sex workers being shooed away from pay and use public toilets, where transgender and male sex workers often pick up and/or service clients. This lack of a secure defensible public space within the city has serious implications for sex workers' livelihoods and lives.

\section{Sex Worker Unionization and the Informal Labor Movement in India}

Many of the challenges in sex workers' path resemble the challenges facing other informal sector workers - especially in feminized sectors considered outside the realm of recognizable economic activity. These challenges require hybrid institutional and legal approaches. For undocumented workers in the United States, for example, organizations have drawn on women's rights, workers' rights, and international human rights frameworks where domestic legal protections are lacking (Ontiveros, 2007). Globally, informal workers' movements have used organizational forms that combine NGO, cooperative, feminist, or membership-based models alongside affiliating with trade unions (Jhabvala, 1998; Chen et al., 2014; Bhowmik, 2008; Bhowmik, 2006; Vosko, 2007), and posed their demands within demands for social security and welfare in addition to traditional workplace protections (Jhabvala, 1998; Agarwala, 2013).

What lies ahead for sex worker unions like KSWU that seek labor union status, but work so differently from formal trade unions? Unionizing has required sex workers to both appeal to the idea of the trade union while also re-imagining it to accommodate issues of identity, stigma, sexuality, gender, patriarchy, and caste. One way to realize this approach (and avoid it being reduced to superficial slogans) has been a politics of alliance: many sex worker unions have connections to umbrella labor federations of progressive unions. But at least in KSWU's case, these links are not always easy to sustain as deeper, lasting partnerships, and KSWU has relied on a broad coalition of supporters from feminist, LGBTI, Dalit, and labor activist backgrounds.

Nevertheless, even if their similarities to other unions and links to the labor movement are somewhat precarious, sex worker unions have the potential to both invigorate the labor movement and benefit from affiliation with informal labor movements (Hardy, 2010). Perhaps even more clearly than other informal workers, sex workers suggest the need for informal worker unions to turn their attention to the state. Sex workers' relationship to the state is one of multiple forms of violence, from forcible HIV testing to police rape to indefinite detention in rehabilitation centers, but it is also to the state that sex worker unions often direct their claims for decriminalization, social services, and basic protections. In the context of sex work, the state is the clearest target for demanding basic social services and human rights. Further, sex worker unions must be able to provide certain services to members in order to meet immediate needs and provide a basic safety net where no other safety net exists. With a multitude of day-to-day challenges, it can be difficult to participate in the work of labor organizing. Sex worker unions like KSWU may also begin to consider demands around legal protections for sexual violence on the job, housing, the regulation of working conditions, or the institution of welfare boards like those available to other informal workers.

Sex worker unions require unique and creative strategies for maintaining contact with workers who are spread out and often working in secret, rather than sharing the same factory floor. They also require a democratic process that actively counters and heals the social divides (between male, female and transgender members, or staff-member or NGO-community hierarchies), divides that have sometimes been reinforced by HIV prevention programs. Finally, as HIV funding is less and less available for reaching sex workers, unions require a sustainable financial model. Funding for sex 
workers' labor rights is not easy to find in comparison to the massive funds once available for HIV prevention. How can unions operate and grow while retaining independence from donors, state agencies, and NGOs that have traditionally been major sources of support?

Despite the challenges of implementing a labor union framework, KSWU members found that positioning themselves as workers allowed them to address immediate concerns as well as the structural inequalities and modes of violence they faced every day. By avoiding unhelpful binaries between victims and criminals, coercion and choice, trafficking and unconstrained sexual freedom, a labor framework allows sex workers to work collectively to solve the problems they perceive as the most important.

Sex workers' creative strategies in adapting a labor framework suggest important considerations for the labor movement in India. First, as with other informal workers in India (Agarwala, 2013), their organizing focuses on access to state welfare, not to employer concessions a focus that becomes particularly important in the context of the contradictory state impulses to criminalize sex workers and monitor their sexual health. The targeting of the state suggests the importance of considerations of criminalization and policing in labor organizing in order to engage diverse kinds of 'workers,' as well as the possibilities (and pitfalls) of state welfare protections for informal workers. Second, their organizing, as with other criminalized and dispersed or flexible groups of workers, has required new strategies for implementing workplace protections - such as peer-to-peer hotlines, demands for police reform, and emotional and social support within the union - that allow for anonymity and draw on hybrid organizational forms. Finally, sex workers' natural affinity and overlap with other groups facing violence and economic marginalization along gender, class, sexuality, and caste lines, as well as elite-focused urban redevelopment projects, has pushed KSWU to pursue alliances with social movements just as much or more than with labor unions - even as they insist on their status as laborers. These alliances demand an approach to the 'union' with a broad analysis of social injustice in a liberalizing state.

At the same time, for KSWU, the demands for organizing are both global and immediate. From the perspective of women and sexual minorities, especially the poorest among them, their labor leading to their livelihood and sense of dignity is of great value. Unionization is an effort to redefine work and wrest a modicum of dignity for an occupation that is socially and legally degraded in both 'traditional' and 'globalized' economies, while simultaneously seeking to build sustainable collective structures that can support their long-term livelihoods and well being.

\section{NOTES}

1. While the main focus of the paper is KSWU, we also make reference to the Indian sex worker movement more generally.

2. Weitzer (1991) is pessimistic about these movements, arguing that they were unable to overcome their stigmatized status enough to achieve lasting change.

3. See http://www.youtube.com/watch?v=bqmVFcrUL8c.

4. According to the Trade Union Act, 1926, a Trade Union can raise or sponsor a trade dispute and represent on behalf of its members in legal proceedings arising out of a trade dispute. Section 13 specifies that upon registration, a trade union gets a legal entity status, due to which it has perpetual succession and a common seal, can acquire and hold movable as well as immovable properties, can contract through agents, and can sue and can be sued. 


\section{REFERENCES}

Agarwala, R. (2013) Informal Labor, Formal Politics, and Dignified Discontent in India. Cambridge University Press.

Agustín, L.M. (2007) Sex at the Margins: Migration, Labour Markets and the Rescue Industry. New York: Zed Books.

Aneka, KSWU, SWaCH, KKPKP, and Krantijyoti Savitribai Phule Women's Studies Centre (2013) Redefining Work: Sex Workers and Wastepickers in Conversation. Bangalore: Aneka.

Baldwin, M.A. (1992) 'Split at the Root: Prostitution and Feminist Discourses of Law Reform,' Yale Journal of Law \& Feminism. 5: 47-120.

Barry, K. (1984) Female Sexual Slavery. New York: NYU Press.

Barry, K. (1996) The Prostitution of Sexuality. New York: NYU Press.

Bernstein, E. (2007) 'Sex Work for the Middle Classes,' Sexualities. 10 (4): 473-88.

Bernstein, E. (2010) Temporarily Yours: Intimacy, Authenticity, and the Commerce of Sex. University of Chicago Press.

Bhowmik, S.K. (2006) 'Cooperatives and the Emancipation of the Marginalized: Case Studies from Two Cities in India,' in B. de Sousa Santos (ed.) Another Production Is Possible: Beyond the Capitalist Canon. London: Verso, pp. 70-94.

Bhowmik, S.K. (2008) 'Labour Organisations in the Twenty-First Century,' Indian Journal of Labour Economics. 51 (4): 958-68.

Bindman, J., and Doezema, J. (1997) Redefining Prostitution as Sex Work on the International Agenda. London: Anti-Slavery International.

Birkinshaw, M. and Harris, V. (2009) “The Right to the 'World Class City?' City Visions and Evictions in Mumbai," The Urban Reinventors. 3/09, pp. 14, 18.

Boris, E., Gilmore, S. and Parreñas, R. (2010) 'Sexual Labors: Interdisciplinary Perspectives toward Sex as Work,' Sexualities. 13 (2): 131-37.

Buzdugan, R., Copas, A., Moses, S., Blanchard, J., Isac, S., Ramesh, B.M., Washington, R., Halli, S.S., and Cowan, F.M. (2010) 'Devising a Female Sex Work Typology Using Data from Karnataka, India,' International Journal of Epidemiology. 39 (2): 439-48.

Buzdugan, R., Halli, S.S., and Cowan, F.M. (2009) 'The Female Sex Work Typology in India in the Context of HIV/AIDS,' Tropical Medicine \& International Health. 14 (6): 673-87.

Census of India. 2001.

Chapkis, W. (1997) Live Sex Acts: Women Performing Erotic Labor. New York: Taylor \& Francis.

Chateauvert, M. (2014) Sex Workers Unite: A History of the Movement from Stonewall to SlutWalk. Boston: Beacon Press. 
Chen, M., Jhabvala, R., Kanbur, R. and Richards, C. (2014) Membership Based Organizations of the Poor. London: Routledge.

Dandona, R., Dandona, L., Kumar, G.A., Gutierrez, J.P., McPherson, S., Samuels, F., Bertozzi, S.M. and ASCI FPP Study Team (2006) 'Demography and Sex Work Characteristics of Female Sex Workers in India,' BMC International Health and Human Rights. 6: (5).

Delacoste, F. and Alexander, P. (1998) Sex Work: Writings by Women in the Sex Industry. San Francisco: Cleis Press.

Dewey, S. (2012) 'The Feminized Labor of Sex Work: Two Decades of Feminist Historical and Ethnographic Research,' Labor. 9 (2): 113-32.

DMSC. (1997) 'Sex Workers' Manifesto,' Theme Paper of the First National Conference of Sex Workers. Calcutta: Durbar Mahila Samanwaya Committee.

Doezema, J. (2001) “Ouch!: Western Feminists 'Wounded Attachment' to the Third World Prostitute," Feminist Review. 67: 16-38.

Dworkin, A. (1993) 'Prostitution and Male Supremacy,' Michigan Journal of Gender \& Law. 1: 1-12.

Ehrenreich, B., and Hochschild, A.R. (2003) Global Woman: Nannies, Maids, and Sex Workers in the New Economy. New York: Macmillan.

Ellis, R. (2012) “'A World Class City of Your Own!': Civic Governmentality in Chennai, India,” Antipode. 44 (4): 1143-60.

Farley, M. (2003) 'Prostitution, Trafficking and Traumatic Stress,' Psychology Press. Vol. 2. pp. 3-4.

Fortunati, L. (1995) The Arcane of Reproduction: Housework, Prostitution, Labor and Capital. Edited by Jim Fleming. Translated by Hillary Creek. New York: Autonomedia.

Gall, G. (2007) 'Sex Worker Unionisation: An Exploratory Study of Emerging Collective Organisation,' Industrial Relations Journal. 38 (1): 70-88.

Gall, G. (2012) An Agency of Their Own: Sex Worker Union Organizing. Washington, DC: Zero Books.

Ghertner, D.A. (2010) 'Calculating without Numbers: Aesthetic Governmentality in Delhi's Slums,' Economy and Society. 39 (2): 185-217.

Ghosh, S. (2004) 'The Shadow Lines of Citizenship: Prostitutes' Struggle over Workers' Rights,' Identity, Culture and Politics. 5 (1-2): 105-23.

Ghosh, S. (2005) 'Surveillance in Decolonized Social Space: The Case of Sex Workers in Bengal,' Social Text. 23 (2): 55.

Grant, M.G. (2014) Playing the Whore: The Work of Sex Work. London: Verso.

Hardy, K. (2010) 'Incorporating Sex Workers into the Argentine Labor Movement,' International Labor and Working-Class History. 77 (01): 89-108. 
Hochschild, A.R. (2003) The Managed Heart: The Commercialization of Human Feeling. Berkeley: University of California Press.

Jana, S., Basu, I., Rotheram-Borus, M.J. and Newman, P.A. (2004) 'The Sonagachi Project: A Sustainable Community Intervention Program,' AIDS Education and Prevention. 16 (5): 40514.

Jenness, V. (1990) 'From Sex as Sin to Sex as Work: COYOTE and the Reorganization of Prostitution as a Social Problem,' Social Problems. 37 (3): 403-20.

Jenness, V. (1993) Making It Work. New York, NY: Aldine de Gruyter.

Jhabvala, R. (1998) 'Social Security for Unorganised Sector,' Economic and Political Weekly. 30, L7L11.

Kempadoo, K. and Doezema, J. (1998) Global Sex Workers: Rights, Resistance, and Redefinition. Psychology Press.

Kotiswaran, P. (2011) Dangerous Sex, Invisible Labor: Sex Work and the Law in India. Princeton University Press.

Lakkimsetti, C. (2011) Governing Sexualities: Globalization, Biopower, and Citizenship in Postcolonial India. Madison: University of Wisconsin-Madison.

Leidholdt, D. (2000) Presentation to UN Special Seminar on Trafficking, Prostitution and the Global Sex Industry. [Online] Available at http://www.catwinternational.org/Content/Images/Article/ 261/attachment.pdf, [Accessed: 15 June 2014].

Leigh, C. (1997) 'Inventing Sex Work,' in Nagle, J. (ed.) Whores and Other Feminists. New York: Routledge, pp. 223-31.

Lim, L.L. (1998) The Sex Sector: The Economic and Social Bases of Prostitution in Southeast Asia. Geneva: International Labor Organization.

MacKinnon, C. (1993) 'Prostitution and Civil Rights,' Michigan Journal of Gender \& Law. 1: 13-31.

MacKinnon, C. (2011) 'Trafficking, Prostitution, and Inequality,' Harvard Civil Rights-Civil Liberties Law Review. 46: 271-309.

Maher, J.M., Pickering, S. and Gerard, A. (2012) Sex Work: Labour, Mobility, and Sexual Services. London: Routledge.

McClintock, A. (1993) 'Sex Work and Sex Workers: Introduction,' Social Text. 37: 1-10.

NACO (2012) Annual Report 2011-12. New Delhi: National AIDS Control Organization, Department of AIDS Control, \& Ministry of Health and Family Welfare.

O’Connell Davidson, J. (2002) 'The Rights and Wrongs of Prostitution,' Hypatia. 17 (2): 84-98. 
Ontiveros, M.L. (2007) 'Female Immigrant Workers and the Law: Limits and Opportunities,' in Cobble, D.S. (ed.) The Sex of Class: Women Transforming American Labor. Ithaca, NY: Cornell University Press, pp. 235-252.

Panchanadeswaran, S., Vijayakumar, G., Chacko, S. and Bhanot, A., forthcoming. 'Unionizing Sex Workers: The Karnataka Experience,' Studies in Law, Politics, and Society.

Pheterson, G. (1993) 'The Whore Stigma: Female Dishonor and Male Unworthiness,' Social Text 37: 39-64.

PUCL (2007) Policing Morality in Channapatna. Bangalore: People's Union for Civil Liberties, Karnataka.

Restakis, J. (2013) Humanizing the Economy: Co-Operatives in the Age of Capital. New Society Publishers.

Rozario, R. (2000) Broken Lives: Dalit Women and Girls in Prostitution in India. Tumkur: Ambedkar Resource Centre, Rural Education for Development Society.

Sahni, R. and Shankar, V.K. (2013) 'Sex Work and Its Linkages with Informal Labour Markets in India: Findings from the First Pan-India Survey of Female Sex Workers,' IDS Working Paper. Vol. 2013, No. 416. [Online] Available at http://opendocs.ids.ac.uk/opendocs/handle/ 123456789/2369, [Accessed: 20 September 2013].

Shah, S. (2003) 'Sex Work in the Global Economy,' New Labor Forum. 12: 74-81.

Sharma, N. (2005) 'Anti-Trafficking Rhetoric and the Making of a Global Apartheid,' NWSA Journal. 17 (3): 88-111.

Soderlund, G. (2005) 'Running from the Rescuers: New US Crusades against Sex Trafficking and the Rhetoric of Abolition,' NWSA Journal. 17 (3): 64-87.

Sukthankar, A. (2012) 'Queering Approaches to Sex, Gender, and Labor in India: Examining Paths to Sex Worker Unionism,' in Loomba, A. and Lukose, R.A. (eds.) South Asian Feminisms. Durham, NC: Duke University Press, pp. 306-32.

Vosko, L.F. (2007) 'Representing Informal Economy Workers: Emerging Global Strategies and Their Lessons for North American Unions,' in Cobble, D.C. (ed.) The Sex of Class: Women Transforming American Labor. Ithaca, NY: Cornell University Press.

Weitzer, R. (1991) 'Prostitutes' Rights in the United States: Failure of a Movement,' The Sociological Quarterly. 32 (1): 23-41.

Weitzer, R. (2007) 'The Social Construction of Sex Trafficking: Ideology and Institutionalization of a Moral Crusade,' Politics \& Society. 35 (3): 447-75.

Weitzer, R. (2009) Sex for Sale: Prostitution, Pornography, and the Sex Industry. Routledge. 


\section{BIOGRAPHICAL NOTE}

GOWRI VIJAYAKUMAR is a Ph.D. candidate in the Department of Sociology at the University of California-Berkeley, USA.

[Email: gowri@berkeley.edu]

SHUBHA CHACKO is the Director of ANEKA, an NGO which fosters social justice for sexual minorities, sex workers, people living with HIV and Dalits in Bangalore, India.

[Email: shubha.chacko@gmail.com]

SUBADRA PANCHANADESWARAN is an Associate Professor at the Adelphi University School of Social Work in New York, USA.

[Email: panchanadeswaran@adelphi.edu] 